\title{
J. REDONDO \& R. TORNÉ (EDS.) (2014). APOCALIPSI, CATÀBASI I MIL·LENARISME A LES LITERATURES ANTIGUES I LA SEUA RECEPCIÓ. ÁMSTERDAM: ADOLF M. HAKKERT. Inés Soler Serrano inessolerserrano@gmail.com Universidad de Córdoba
}

Recibido: 24 octubre 2016 Aceptado: 7 noviembre 2016

J. Redondo \& R. Torné (eds.) (2014). Apocalipsi, catàbasi $i$ mil.lenarisme a les literatures antigues i la seua recepció. Ámsterdam: Adolf M. Hakkert. ISBN: 978-90-256-1292-4.

Con esta publicación, el Grupo de Investigación de la Recepción de las Literaturas Clásicas (GIRLC), con sede en la Universidad de Valencia, continúa con sus estudios sobre temas universales tratados en la literatura de sociedades antiguas y su proyección en culturas posteriores. Se investigan cuestiones relativas a la escatología en la tradición clásica, especialmente la catábasis o viaje a los infiernos, así como el discurso apocalíptico y milenarista. Como fundamento de esta tarea filológica se encuentra la traducción fiel de los textos clásicos; se previene, de este modo, que los investigadores apoyen sus trabajos exclusivamente en planteamientos teóricos previos, alejados de la realidad del propio texto.

J. Teodoro en su contribución "Viure a l'infern. El món dels morts al món dels vius" (pp. 267-291) repasa algunas concepciones del inframundon desarrolladas en el neoplatonismo. La revisión presta especial atención a sus orígenes mesopotámicos, egipcios y hebreos, y estudia, además, los pasajes mitológicos de Platón que tratan este tema. En segundo lugar, rastrea la adaptación de dichas nociones en la filosofía neoplatónica renacentista: el autor se centra en el Zodiacus Vitae del humanista italiano Marcello Palingenio Stellato. Por otra 
parte, R. Torné en "Lírics grecs i l'inframón” (pp. 293-305) también centra su investigación en el examen de diferentes conceptos relacionados con la muerte y el más allá. Para ello se sirve de los testimonios de poetas líricos griegos, desde época arcaica hasta la helenística.

Entre las investigaciones dedicadas al Inframundo destaca "Amor más allá de la muerte: o cómo imaginan los poetas a los enamorados en el Infierno" (pp. 11-41), de G. Laguna Mariscal. En este artículo se estudia la combinación de las nociones de Amor y Muerte y se establecen las relaciones que pueden existir entre ambos. El autor estudia también los rasgos de pasajes de la escena de los enamorados en el Más Allá y su recepción en la cultura literaria posterior, desde Homero hasta la película Desmontando a Harry de Woody Allen, pasando conspicuamente por la catábasis virgiliana del libro VI de la Eneida, Dante y el género "Infiernos de Enamorados". M. Martínez Sariego, por su parte, analiza, en "Locus solus y otras galerías infernales: De Homero a Raymond Roussel" (pp. 43-62), esta narración vanguardista contemporánea y determina la influencia de catabásis que proceden de textos clásicos y medievales.

Muchos de los textos clásicos que trataron la vida de Dioniso lo vinculan con el mundo de la muerte. En concreto, M. A. Santamaría (pp. 217-240) estudia en esta publicación el descenso del dios al Hades en busca de su madre y su recepción en la literatura latina y cristiana. Se centra en las fuentes del mito, los motivos que presenta (apoteosis, liberación del Inframundo y catábasis de Dioniso) y su desarrollo como motivo a lo largo del tiempo. J. R. Montañés (pp. 63-80) realiza una aproximación a la catábasis en la literatura griega cretense, mediante el estudio en paralelo del Apokopos de Bergadís y la Rima de Pikatoros. El objetivo primordial del autor es establecer las semejanzas y diferencias de ambos textos, a través del análisis de su argumento, fuentes, estructura y sus componentes característicos.

En relación con la literatura hispánica surgida en torno a este tema destaca "Elements de tradició clàssica en El somni de l'infern de Pere Jacint Morlà" (pp. 119-130), de J. Pérez Asencio. Esta obra del poeta valenciano contiene elementos relacionados con la Comedia, entre 
ellos una parodia del mito de Orfeo. Además, el texto incluye motivos y componentes de la literatura griega clásica, como el sueño asociado al mundo de ultratumba y el viaje al Infierno. De igual modo, M. A. Sequero analiza un texto catalán en "La història del Cavaller Partinobles: la dama-fada viatgera entre diferents móns" (pp. 241254), una novela donde no se trata el tema del viaje al Inframundo al estilo clásico, pero sí como una realidad paralela que acontece en los encantamientos de una doncella. La autora se interesa por el estudio de las herramientas literarias tomadas por el escritor de diferentes ámbitos: del folclore, de la tradición artúrica y medieval y del género de la novela.

Otro tema relacionado con la dimensión del mundo de los muertos es la Necromancia. J. J. Pomer Monferrer (pp. 131-142) analiza en esta publicación un episodio del libro VI de las Etiópicas de Heliodoro: el único pasaje de necromancia de la novela griega antigua. En este trabajo compara el texto con sus precedentes, Homero, Esquilo y Heródoto, y examina los ritos egipcios que se describen en él; además, establece los elementos novelescos presentes en el texto. C. Sánchez Mañas también estudia un episodio de nigromancia en "Oráculo de los muertos de los tesprotos (Hdt. V 92ๆ)" (pp. 201-215). En este caso, Heródoto describe en sus Historias el momento en el que los mensajeros de Periandro consultan a su difunta esposa, Melisa, acerca del lugar donde ella escondía cierta cantidad de dinero. La autora explora el contenido y la formulación de las dos respuestas del fantasma desde un punto de vista léxico-estilístico.

Uno de los principales ámbitos de investigación de este libro es el discurso apocalíptico. En concreto aparecen dos artículos relacionados con el desarrollo de este tema en la tradición cristiana: "Tormentas apocalípticas en la literatura griega cristiana" (pp. 81-95), de A. Narro; y "Dal dolore alla speranza (1Ts 4, 13-5,11)", de C. Neri (pp. 97-118). En el primero, Narro estudia la Vida de los Milagros de Tecla y los Hechos del apóstol Pablo, fijando el foco de atención en el concepto de "tormenta" ( $\chi \alpha \dot{\lambda} \lambda \alpha \zeta \alpha)$ como herramienta divina para castigar a los pecadores. Para ello, analiza los paralelismos que existen entre estos textos y algunos pasajes del Antiguo Testamento, las Historias de 
Herodoto y las Etiópicas de Heliodoro. Por su lado, Neri presenta una exégesis de la Primera epístola a los Tesalonicenses de Pablo y lo relaciona con otras dos de sus epístolas. En cada texto expone una de las tres virtudes teologales del apóstol: fe, caridad y esperanza. Ésta última es abordada en la Carta a los tesalonicenses, que incluye numerosas referencias a temas de tipo apocalíptico.

El tópico del apocalipsis no es sólo propio de la cultura cristiana. Así, D. Rull presenta, en "El Llibre de la Vaca Celeste: el mite de la destrucció de la humanitat a l'Antic Egipte" (pp. 183-200), la traducción al catalán de uno de los textos escatológicos más antiguos de la literatura universal. El Libro de la Vaca Celeste es un texto egipcio del siglo XIV a. C., en el que se narra la refundación del universo una vez destruida la humanidad. Finalmente, como última investigación sobre esta temática, destaca el artículo de K. K. Starcewska: "Quum Turcae ritu Antichristiano iam grassentur, la amenaza otomana vista como castigo para el mundo cristiano" (pp. 255-266). La autora explica cómo algunos autores latinos cristianos utilizaron los tópicos preexistentes sobre el Anticristo y el Apocalipsis para predicar contra los turcos. Por ejemplo, en el contexto de la invasión árabe de la Península Ibérica, Mahoma es presentado como el anticristo o un hereje en este tipo de textos; mientras que, para los cristianos, la Caída de Constantinopla supuso un castigo por sus transgresiones y excesos.

Otros autores de la época de la conquista turca de Bizancio relacionaron este suceso con la escatología milenarista. Este es el caso del escritor anónimo de Complants per la presa de Constantinoble y de su modelo la Invocación de Constantinopla. Ambos textos son estudiados por J. Redondo (pp. 157-182), quien además establece la configuración de los tópicos literarios desde la conquista de Troya (Ilíada, s. XIII a. C.) hasta la Baja Edad Media. El último trabajo incluido en esta monografía es el titulado "Assimilació d'idees a l'escatologia mil-enarista de Lactanci: les cites virgilianes" (pp. 143156) de L. Pomer Monferrer. Este investigador analiza los contenidos milenaristas incluidos en el libro VII de las Divinae institutiones de Lactancio: presta especial atención a las diversas fuentes incorporados 
por el escritor latino, como los escritos de Virgilio, de Cicerón y de Séneca.

Este volumen, auspiciado por el Grupo de Investigación de la Recepción de las Literaturas Clásicas, resulta enriquecedor, debido a que ofrece una visión amplia y variada sobre los temas interrelacionados de la catábasis, el apocalipsis y el milenarismo (además de otros temas escatológicos relacionados con la muerte). El objetivo que persigue dicho grupo -y que aparece de manera expresa en su prólogo- queda implementado: en las investigaciones se abarca el estudio de diversas literaturas y épocas; desde textos egipcios de hace más de dos mil años hasta novelas contemporáneas. Además, con estos artículos se demuestra la gran relevancia que tuvieron los temas escatológicos en sociedades y culturas de diferentes épocas y lugares. Sin embargo, un posible problema que puede encontrar el lector, derivado de la variedad de los temas tratados, podría consistir en la descompensación entre los capítulos presentados para cada uno de ellos. Así, por ejemplo, la cuestión del milenarismo está poco representada, mientras que se ha insistido en el tópico de la catábasis, de forma que se incurre en ciertas reiteraciones. 